\title{
Differential expression of upstream stimulatory factor (USF) 2 variants in eutopic endometria from women with endometriosis: estradiol regulation
}

Jazmin Castro ${ }^{1}$, Germán Araya', Pamela Inostroza ${ }^{1}$, Paulina Hidalgo' ${ }^{1}$, Reinaldo González-Ramos \$,2, Hugo Sovino ${ }^{1,2}$, M. Angélica Boric ${ }^{1}$, Ariel Fuentes ${ }^{1,2}$ and M. Cecilia Johnson ${ }^{1 *}$

\begin{abstract}
Background: Endometriosis, pro-inflammatory and invasive benign disease estrogen dependent, abnormally express in endometria the enzyme $\mathrm{P}_{450}$ Arom, positively regulated by steroid factor-1 (SF-1). Our objective was to study the nuclear protein contents of upstream stimulating factor 2 (USF2a and USF2b), a positive regulator of SF-1, throughout the menstrual cycle in eutopic endometria from women with and without (control) endometriosis and the involvement of nuclear estrogen receptors (ER) and G-coupled protein estrogen receptor (GPER)-1.

Results: Upstream stimulating factor 2 protein contents were higher in mid (USF2b) and late (USF2a and USF2b) secretory phase in eutopic endometria from endometriosis than control $(p<0.05)$. In isolated control epithelial cells incubated with $E_{2}$ and $\mathrm{PGE}_{2}$, to resemble the endometriosis condition, the data showed: (a) significant increase of USF2a and USF2b nuclear protein contents when treated with $E_{2}$, PPT (specific agonist for ER $\alpha$ ) or G1 (specific agonist for GPER1); (b) no increase in USF2 binding to SF-1 E-Box/DNA consensus sequence in $\mathrm{E}_{2}$-treated cells; (c) USF2 variants protein contents were not modified by $\mathrm{PGE}_{2}$ (d) SF-1 nuclear protein content was significantly higher than basal when treated with $\mathrm{PGE}_{2}, \mathrm{E}_{2}$ or $\mathrm{G} 1$, stimulation unaffected by ICI (nuclear ER antagonist); and (e) increased ( $p<0.05$ ) cytosolic protein contents of $\mathrm{P}_{450}$ Arom when treated with $\mathrm{PGE}_{2}, \mathrm{E}_{2}$, PPT or G1 compared to basal, effect that was additive with $E_{2}+P G E_{2}$ together. Nevertheless, in endometriosis cells, the high USF2, SF-1 and P450Arom protein contents in basal condition were unmodified.

Conclusion: These data strongly suggest that USF2 variants and $P_{450}$ Arom are regulated by $E_{2}$ through $E R \alpha$ and GPER1, whereas SF-1 through GPER1, visualized by the response of the cells obtained from control endometria, being unaffected the endogenously stimulated cells from endometriosis origin. The lack of $E_{2}$ stimulation on USF2/SF-1 E-Box/DNA-sequence binding and the absence of $\mathrm{PGE}_{2}$ effect on USF2 variants opposite to the strong induction that they exert on SF1 and P450 proteins suggest different mechanisms and indirect regulations. The sustained USF2 variants protein expression during the secretory phase in eutopic endometria from women with endometriosis may participate in the pathophysiology of this disease strongly associated with infertility and its characteristic endometrial invasion to ectopic sites in the pelvic cavity.
\end{abstract}

Keywords: USF2, GPER1, Endometriosis, Eutopic endometrium, Estrogen receptor, Estrogen receptor specific agonists, SF-1, $\mathrm{P}_{450}$ Arom

\footnotetext{
*Correspondence: cjohnson@med.uchile.cl

${ }^{1}$ Faculty of Medicine, Institute of Maternal and Child Research, University

of Chile, P.O. Box 226-3, Santiago, Chile

Full list of author information is available at the end of the article
} 


\section{Background}

Endometriosis is an estrogen-dependent gynecologic disease, characterized by the presence and growth of endometrium outside the uterine cavity. This pathology affects about $10 \%$ of reproductive-age women and is associated with infertility, chronic pelvic pain, dysmenorrhea, and dyspareunia [1-4]. The etiology of this disease remains incompletely understood [5]. Retrograde menstruation with viable endometrial fragments has been advocated as one of the mechanisms by which the endometrium reaches the peritoneal cavity [6]. However, this theory fails to explain why only a select group of women experiencing retrograde menstruation develops endometriosis [7].

Endometrial estrogenic microenvironment has been shown to be an important factor in the pathophysiology of endometriosis by abnormal expression of enzymes involved in estrogen synthesis and degradation $[8,9]$. The activation of CYP19A1 gene induces $\mathrm{P}_{450}$ Arom expression, the rate-limiting enzyme in conversion of androgens to estrogens. Normally, steroid factor-1 (SF-1) positively regulates the CYP19A1 gene in the ovary, though not in the normal endometrium. Nevertheless, SF-1, expressed in eutopic and ectopic endometria from women with endometriosis, aberrantly activates CYP19A1 and the expression of $\mathrm{P}_{450}$ Arom in stroma [10-12] or gland [13, 14] in these tissues as has been extensively described favoring this estrogenic microenvironment in this disease.

SF-1 gene is recognized in a region called E-box by upstream stimulatory factor (USF), the ubiquitous transcription factor involved on embryonic development, fertility, stress, growth and lipid and carbohydrate metabolisms $[15,16]$. Although two types of USF, USF1 and USF2, have been reported, it is USF2 that shows the highest binding activity on SF-1 promoter and its knockdown results in down-regulation of SF-1 and also of its target gene CYP19A1 in ectopic endometrium from endometriosis women [17]. Two variants of USF2, produced by alternative splicing, have been reported, the bigger USF2a $(44 \mathrm{kDa})$ and the smaller USF2b ( $38 \mathrm{kDa}$ ) by the loss of 67 internal amino acid in the $\mathrm{N}$-terminal domain $[15,18]$.

Estradiol $\left(E_{2}\right)$ acts through the classic nuclear estrogen receptors (ER), ER $\alpha$ and $E R \beta$, both strictly regulated by the ovarian steroid hormones during the menstrual cycle, with a predominance of ER $\alpha$ over ER $\beta$ in the normal endometrium and reducing their expression during the secretory phase [19-22]. In eutopic endometrium from women with endometriosis, although each ER isoforms are increased, the $E R \alpha / E R \beta$ ratio is decreased affecting the normal actions of $E_{2}$ in this tissue [23, 24]. In addition, a membrane receptor called G-protein estrogen receptor 1 (GPER1) presents high affinity for $E_{2}$ in vitro $[25,26]$ and has been described as potentially responsible of early and non genomic responses of estrogen in several cell lines and tissues including the endometrium [27-29].

The aberrant expression of CYP19A1 and SF-1 genes in eutopic and ectopic endometria of women with endometriosis led us to study USF2 variants protein contents in human endometrium throughout the menstrual cycle and the effect of estrogenic and proinflammatory environments in epithelial cells of eutopic endometrium from women with and without endometriosis. The involvement of nuclear $E R \alpha, E R \beta$ or GPER1 in the $E_{2}$ action on USF2 variants, SF-1 and P450Arom protein expression was also evaluated.

\section{Results}

USF2 protein contents in endometrium throughout the menstrual cycle

The protein content of both USF2a and USF2b variants were detected by immunoblot (Fig. 1) in endometrium from women with endometriosis and controls. No interactions between USF2 protein studies and subject age was found by ANCOVA.

Two protein bands ( 44 and $38 \mathrm{kDa}$ ), corresponding to USF2a and USF2b variants, respectively, were found in the nuclear compartment of control and endometriosis endometria (Fig. 1). In control endometria, nuclear USF2a protein content decreased in early and late secretory phases (37 and $57 \%$, respectively, $\mathrm{p}<0.05$ ) as compared to the proliferative phase. On the other hand, in endometriosis, USF2a contents were lower during the late secretory as compared to the mid secretory phase, although higher than late control endometria (Fig. 1a).

During mid and late secretory phases, USF2b ( $38 \mathrm{kDa})$ nuclear protein content significantly decreased (39 and $34 \%$, respectively) as compared to proliferative phase in control endometria, instead it was observed an increase in endometriosis endometria during the same stages of the menstrual cycle, being higher 100 and $155 \%$, respectively, than control (Fig. 1b).

\section{Stimulatory effect of $E_{2}$ and PGE2 on USF2, SF-1 and $\mathrm{P}_{450}$ Arom protein contents}

In endometriosis epithelial cells, nuclear protein contents of USF2a and USF2b were significantly higher in basal condition than control cells. Nevertheless, only in control cells, $\mathrm{E}_{2}$ increased USF2a (103 \%) and USF2b (91 \%) nuclear protein contents, effect also partially blocked by the presence of ICI (Fig. 2a, b). Nuclear protein homogenate obtained from control and endometriosis epithelial cells bound to target E-Box motif, complexes displaced by cold probe. The previous incubation of the nuclear protein homogenates with USF2 antibody shifted partially the protein/E-Box complex in basal or E2-treated conditions (Fig. 2c).

We observed a null effect on USF2a and USF2b nuclear protein contents of $10^{-8} \mathrm{~mol} / \mathrm{L} \mathrm{PGE}_{2}$, in the presence or 

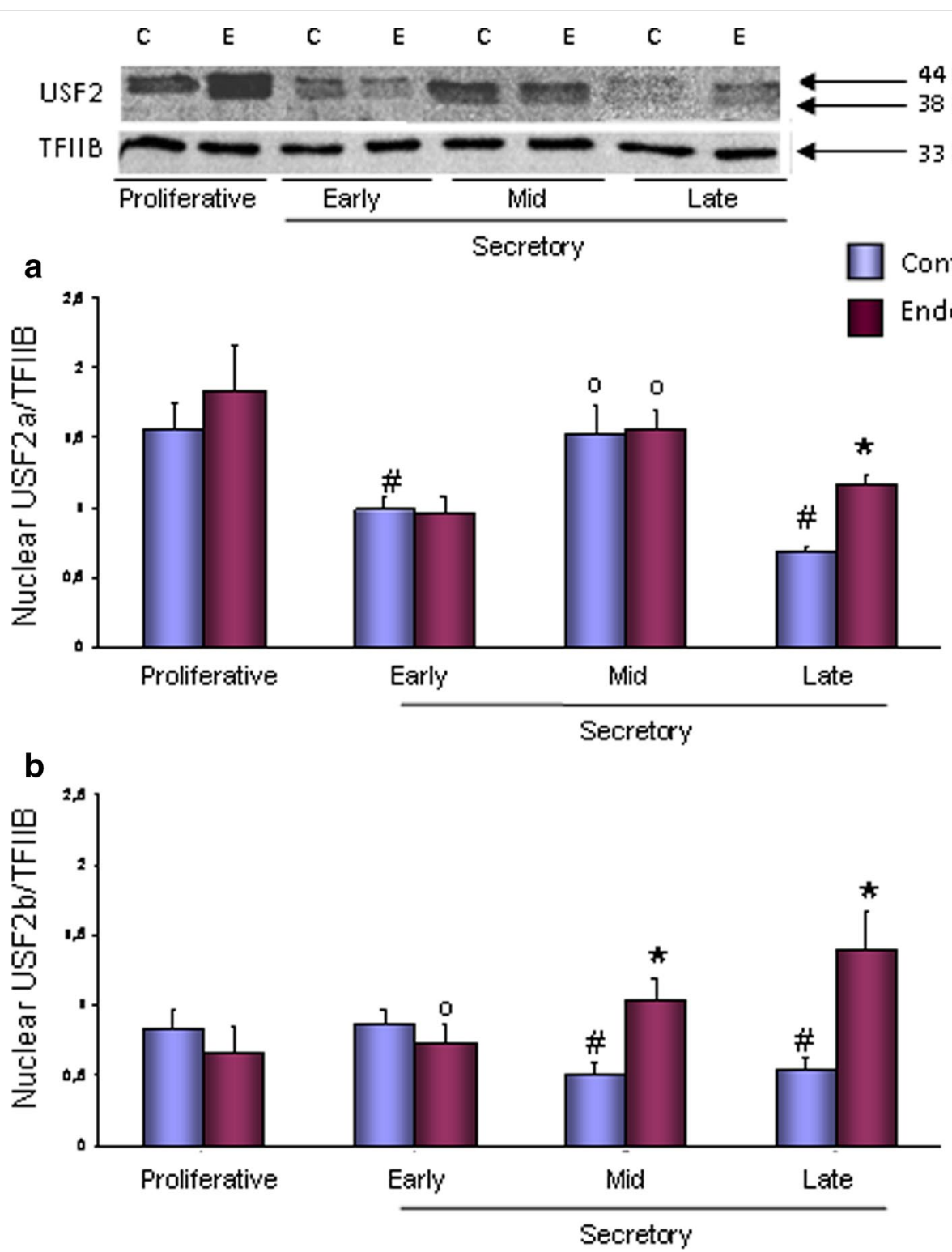

Fig. 1 USF2a (a) and USF2b (b) nuclear protein contents in eutopic endometria throughout the menstrual cycle. Endometria were obtained from seven women without (control) and seven women with endometriosis in each stage of the menstrual cycle. Representative immunoblots are shown. Data were normalized with TFIIB protein contents. Results are the mean $\pm \mathrm{SEM}$. ${ }^{*} \mathrm{p}<0.05 \mathrm{vs}$. control; ${ }^{\#} \mathrm{p}<0.05 \mathrm{vs}$. proliferative phase; op $<0.05$ vs. late secretory phase

absence of $10^{-8} \mathrm{~mol} / \mathrm{L} \mathrm{E}_{2}$ in isolated epithelial cells from both control and endometriosis endometria (Fig. 2a, b).

Epithelial cells obtained from endometriosis endometria had high SF-1 protein expression in basal condition, which were resistant to $\mathrm{E}_{2}$ and $\mathrm{PGE}_{2}$ (Fig. 3a). On the contrary, in control epithelial cells, the SF-1 protein content was strongly increased by $\mathrm{E}_{2}(126 \%)$ as compared to basal, effect not modified by the presence of ICI. The presence of $\mathrm{PGE}_{2}$ also increased the content of SF-1 protein $(154 \%)$ as compared to basal, although no additive or synergistic effects were observed when $\mathrm{E}_{2}$ and $\mathrm{PGE}_{2}$ were added together (Fig. 3a).

Similarly to SF-1 protein results, the cytosolic protein content of $\mathrm{P}_{450}$ Arom was strongly high in epithelial cells from endometriosis endometria in basal condition, and also resistant to $\mathrm{E}_{2}$ and $\mathrm{PGE}_{2}$ presences (Fig. $3 \mathrm{~b}$ ). In control epithelial cells, $\mathrm{P}_{450}$ Arom protein content was significantly increased by $\mathrm{E}_{2}$ (292\%), effect partially blocked by ICI pre-treatment. $\mathrm{PGE}_{2}$ increased $(258 \%$ ) the protein content of $\mathrm{P}_{450}$ Arom and the presence of both, $\mathrm{E}_{2}$ and 

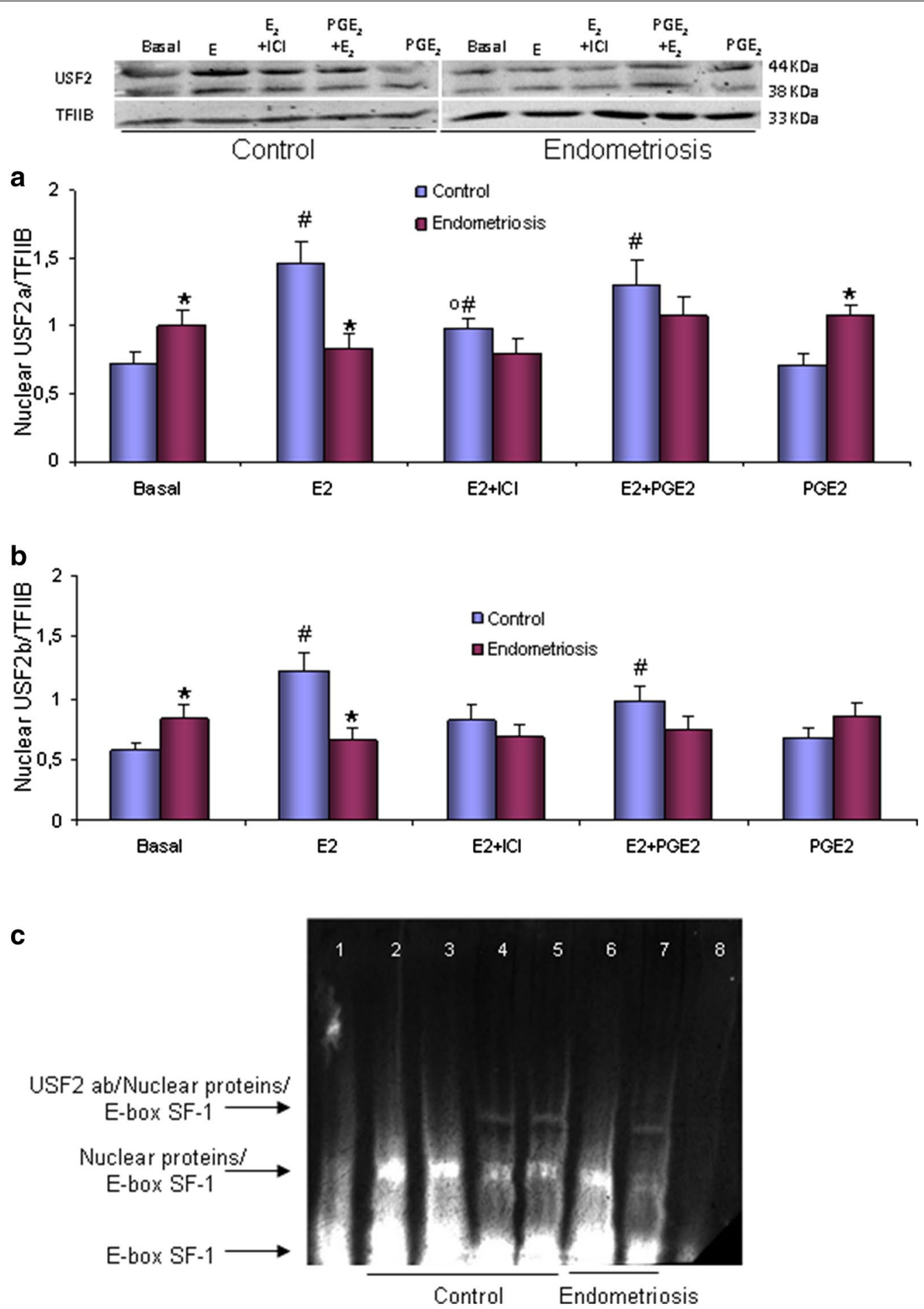

Fig. $2 E_{2}$ and PGE $E_{2}$ effect on USF2 variants protein contents and SF-1 E-Box DNA binding. USF2a (a) and USF2b (b) nuclear protein contents of endometrial epithelial cells (EEC) from women with and without (control) endometriosis treated with $\mathrm{E}_{2}\left(10^{-8} \mathrm{~mol} / \mathrm{L}\right)$ and/or $\mathrm{PGE}_{2}\left(10^{-8} \mathrm{~mol} / \mathrm{L}\right)$ in the presence or absence of $\mathrm{ICl}\left(10^{-6} \mathrm{~mol} / \mathrm{L} ; 30 \mathrm{~min}\right.$ previously added); all data were normalized with TFIIB. Representative immunoblot is shown. Results are the mean \pm SEM of EEC obtained from 7 control women and 7 women with endometriosis. c Representative SF-1 E-Box DNA shift assay from 3 gels. Lane 1 free probe; lanes $2-5$ nuclear protein from control EEC (2 basal condition; $3 \mathrm{E}_{2}$ treated; 4 basal + anti USF2 antibody; $5 \mathrm{E}_{2}+$ anti USF2 antibody); lanes 6 and 7: nuclear protein from endometriosis endometrial epithelial cells ( 6 basal condition; 7 basal + anti USF2 antibody), and lane 8 basal condition + cold competitor. Protein procurements and assays are described in "Methods". * $p<0.05$ control; " $p<0.05$ vs. baseline; op $<0.05$ vs. $E_{2}$ 


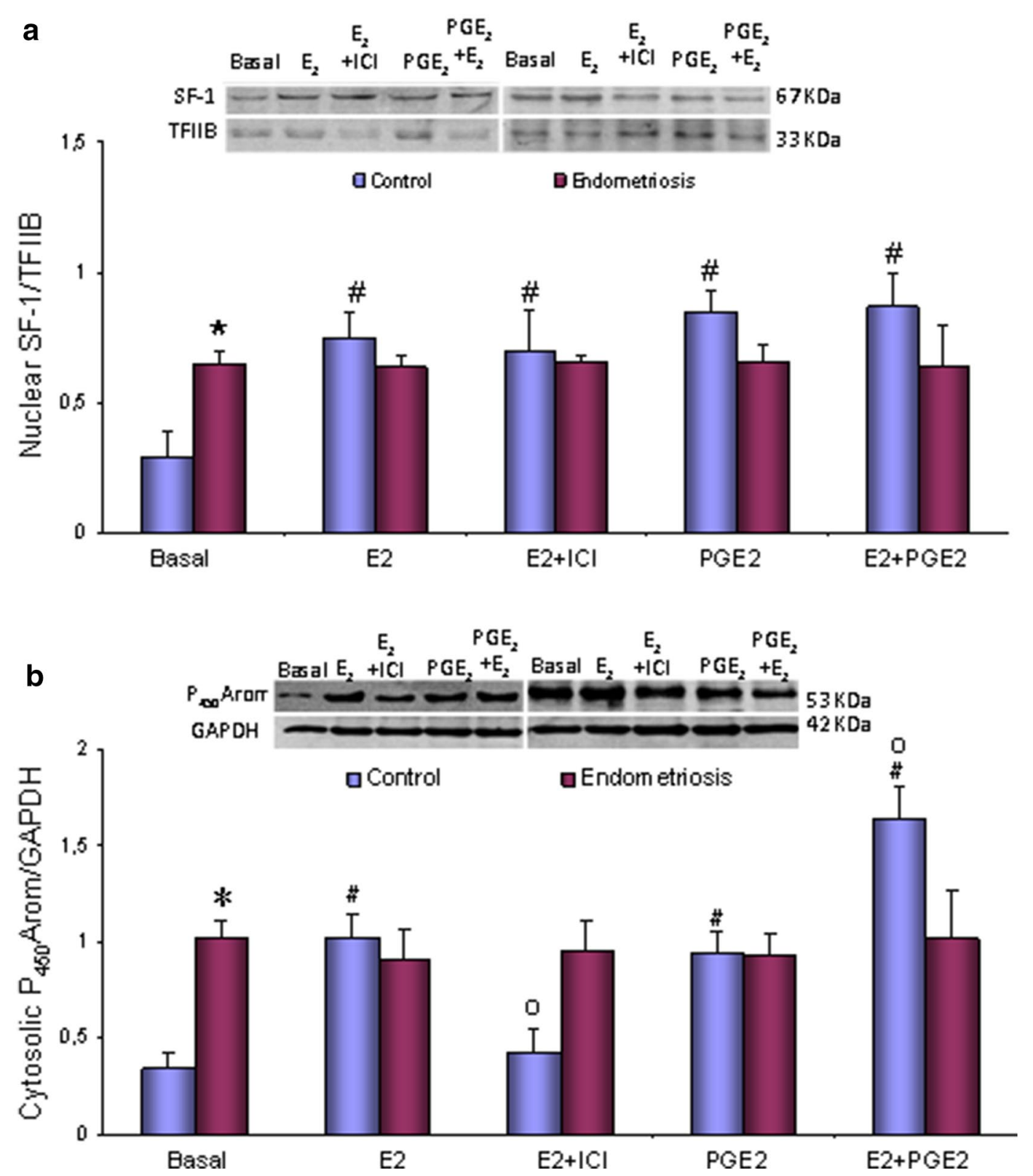

Fig. $3 E_{2}$ and $P G E_{2}$ effect on SF-1 and $P_{450}$ Arom protein levels in endometrial epithelial cells. Isolated endometrial epithelial cells (EEC) obtained from 4 to 6 women with or without (control) endometriosis were treated for $24 \mathrm{~h}$ with $E_{2}\left(10^{-8} \mathrm{~mol} / \mathrm{L}\right)$ and $/ \mathrm{or} \mathrm{PGE}_{2}\left(10^{-8} \mathrm{~mol} / \mathrm{L}\right)$ in the presence and absence of $\mathrm{ICl}\left(10^{-6} \mathrm{~mol} / \mathrm{L} ; 30 \mathrm{~min}\right.$ previously added). Representative immunoblots are shown. Data for SF-1 (nuclear homogenates) were normalized with TFIIB (a) and for P450Arom (cytosol homogenates) with GAPDH (b). Results are the mean \pm SEM. ${ }^{*} \mathrm{p}<0.05$ vs.control; ${ }^{\#} p<0.05$ vs. basal, ${ }^{\circ} \mathrm{p}<0.05$ vs. one treatment

$\mathrm{PGE}_{2}$, shows an additive effect (525\%) on the protein content (Fig. 3b).

Specific agonists of estrogen receptors involved on USF2, SF-1 and $P_{\mathbf{4 5 0}}$ Arom protein content by $E_{\mathbf{2}}$ stimulation Taking into account that cells obtained from endometriosis women are highly endogenously stimulated, control epithelial cells were used for the following experiments to assess the ER isoform involvement. For that, control cells were incubated with specific agonists for $\mathrm{ER} \alpha(\mathrm{PPT}), \mathrm{ER} \beta$ (DPN) and GPER1 (G1).

These cells responded to PPT at $10^{-7} \mathrm{~mol} / \mathrm{L}$ and $\mathrm{G} 1$ at $10^{-6} \mathrm{~mol} / \mathrm{L}$, increasing the protein content of USF2a by 153 and $164 \%$ and USF2b by 169 and $109 \%$, respectively 
$(\mathrm{p}<0.05)$. The stimulatory effect of PPT was blocked by the presence of ICI. Paradoxically, ICI alone increased both USF2 variants. No significant effect was observed with DPN (Fig. 4a, b).

Only G1 increased SF-1 nuclear protein content by $250 \%$ at $10^{-6} \mathrm{~mol} / \mathrm{L}$ in the control cells (Fig. 5a). Similarly to SF-1, $\mathrm{P}_{450}$ Arom cytosolic protein content was increased in a dose-dependent manner by G1 (242\%) and also by PPT (232 \%) as compared to basal condition (Fig. 5b).

\section{Discussion}

To our knowledge, this is the first report on human endometrial USF2a and USF2b protein co-expression throughout the menstrual cycle, and their positive regulation by $\mathrm{E}_{2}$ through $\mathrm{ER} \alpha$ and GPER1.
The reduced nuclear protein content of USF2 variants during the late secretory phase in control endometria is consistent with the decreased plasma $E_{2}$ and progesterone levels during this period of the menstrual cycle. In contrast, eutopic endometria from endometriosis patients exhibited high USF2 variants protein contents during this stage coincidently with the estrogenic microenvironment described in the eutopic and ectopic endometria of these patients [10,13,14, 30-32]. On the other hand, the opposite expression of USF2a and USF2b found in control endometria during the mid secretory phase, when the embryo implantation occurs, was not observed in eutopic endometria from endometriosis women, which may contribute to the infertility associated to this pathology. The different expression patterns

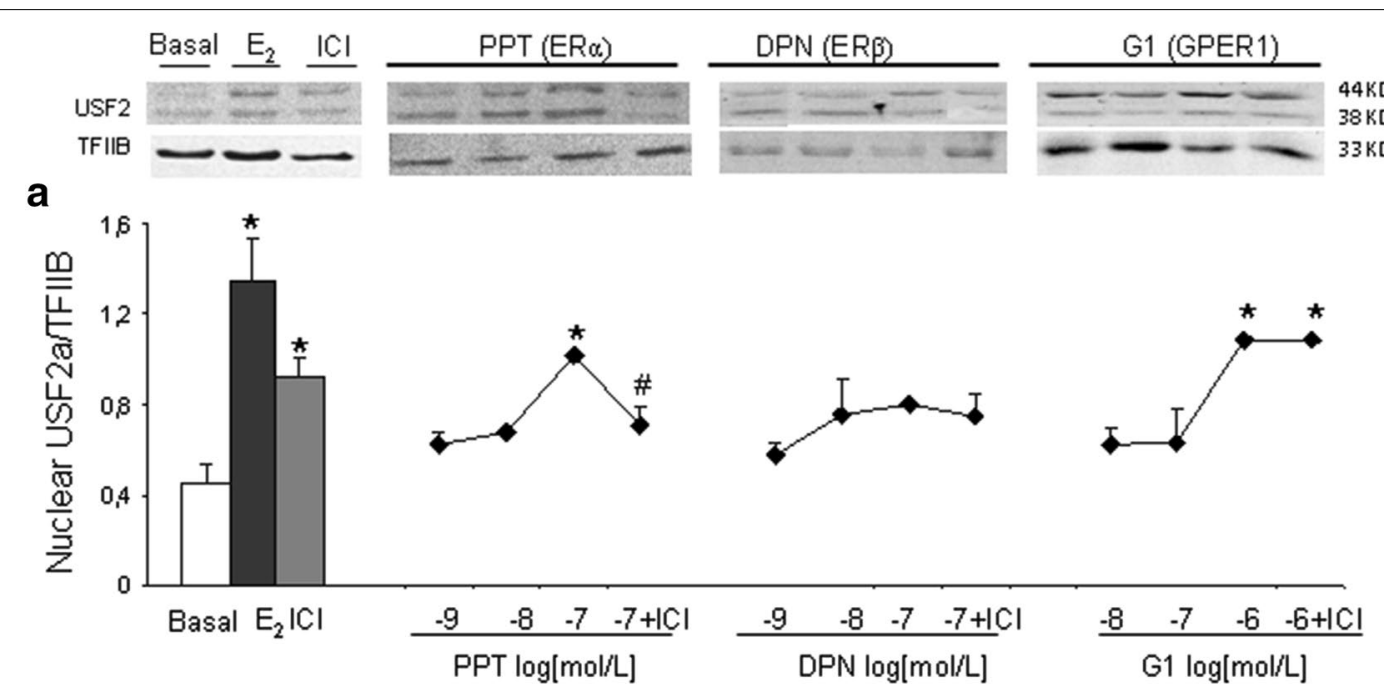

b

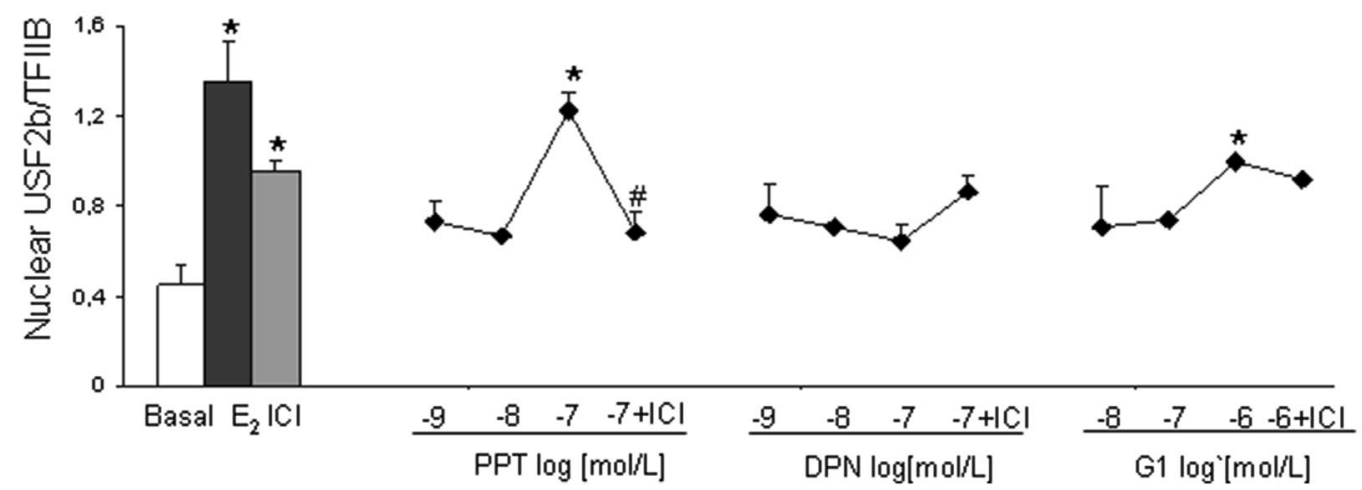

Fig. 4 Dose-response curves of specific agonists on USF2a (a) and USF2b (b) nuclear protein content. Endometrial epithelial cells obtained from 4 control women were treated for $24 \mathrm{~h}$ with $\mathrm{E}_{2}\left(10^{-8} \mathrm{~mol} / \mathrm{L}\right), \mathrm{PPT}\left(10^{-9}\right.$ to $\left.10^{-7} \mathrm{~mol} / \mathrm{L}\right)$, DPN $\left(10^{-9}\right.$ to $\left.10^{-7} \mathrm{~mol} / \mathrm{L}\right)$, and $\mathrm{G} 1\left(10^{-8}\right.$ to $\left.10^{-6} \mathrm{~mol} / \mathrm{L}\right)$ in the presence or absence of $\mathrm{ICI}\left(10^{-6} \mathrm{~mol} / \mathrm{L} ; 40 \mathrm{~min}\right.$ previously added). Representative immunoblot is shown. Data were normalized with TFIIB. Results are the mean \pm SEM of EEC obtained from at least 4 control women. ${ }^{*} p<0.05$ vs. basal; ${ }^{*} p<0.05$ vs. agonist 

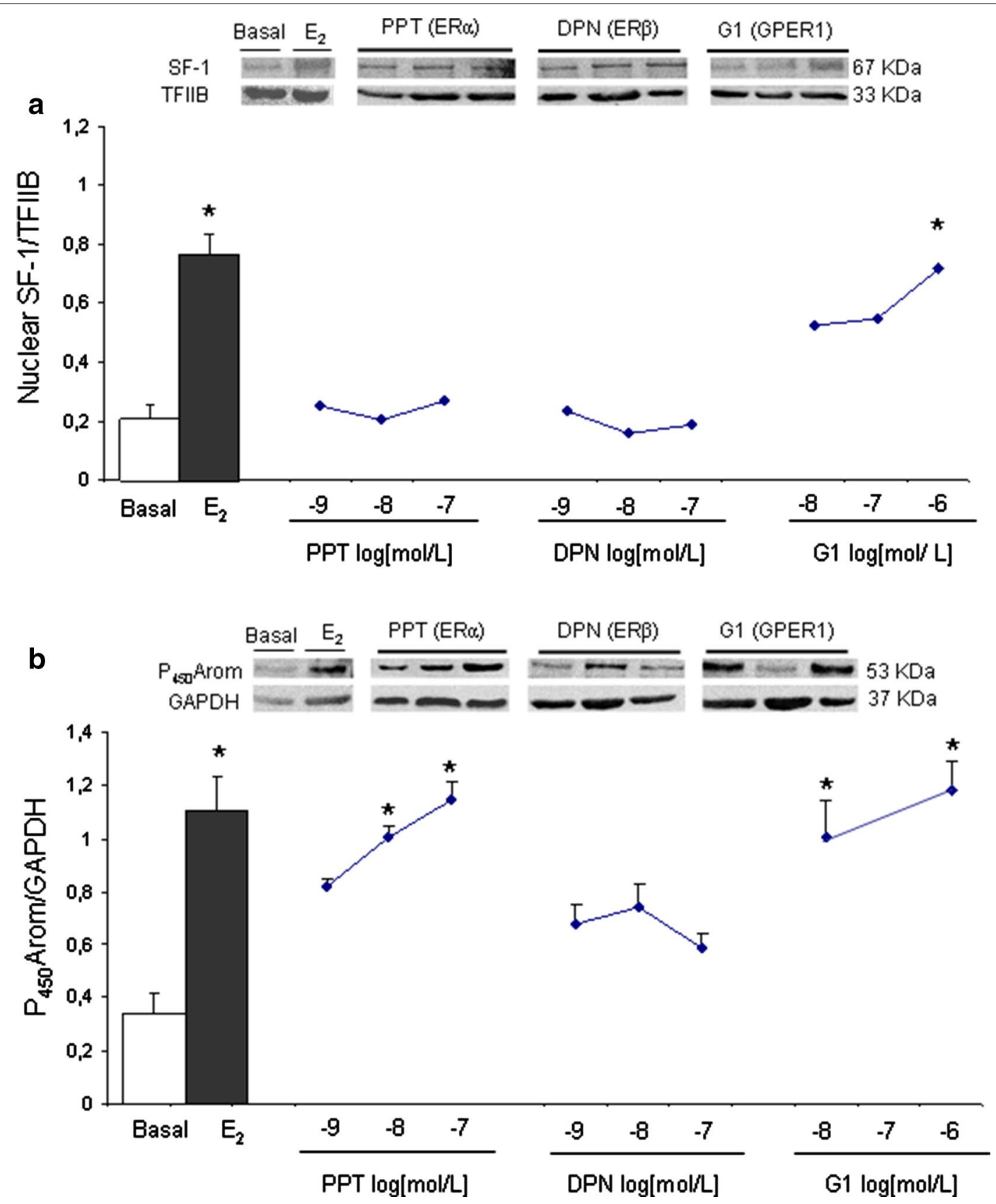

Fig. 5 Dose-response curves of specific agonists on SF-1 (a) and $\mathrm{P}_{450}$ Arom (b) protein content. Endometrial epithelial cells obtained from 4 control women were treated with $\mathrm{E}_{2}\left(10^{-8} \mathrm{~mol} / \mathrm{L}\right)$, PPT $\left(10^{-9}\right.$ to $\left.10^{-7} \mathrm{~mol} / \mathrm{L}\right)$, DPN $\left(10^{-9}\right.$ to $\left.10^{-7} \mathrm{~mol} / \mathrm{L}\right)$, and $\mathrm{G} 1\left(10^{-8}\right.$ to $\left.10^{-6} \mathrm{~mol} / \mathrm{L}\right)$. Representative immunoblots are shown. Data for SF-1 (nuclear homogenates) were normalized with TFIIB and for P450Arom (cytosol homogenates) with GAPDH. Results are the mean \pm SEM. ${ }^{*} p<0.05$ vs. basal

of endometrial USF2 variants between women with and without endometriosis throughout the menstrual cycle add new molecules to those abnormally expressed in this tissue as has been widely reported [33-36]

We observed a strong $E_{2}$-stimulatory effect on USF2 variants nuclear protein contents in epithelial cells from control endometria. These findings are supported by the epithelial cells response to ICI, an antagonist of ER $\alpha$ and $E R \beta$, which partially blocked those effects induced by $\mathrm{E}_{2}$, but completely blocked those induced by PPT (specific agonist of $E R \alpha$ ) and acting as agonist for GPER1, unaffected those effects induced by G1 (specific agonist 
of GPER1), confirming the dual action of ICI on estrogen receptors [37]. These data suggest that this process is under ovarian steroid regulation through the classic nuclear ER $\alpha$ and also GPER1. Interestingly, positive regulation of the ER $\alpha$ expression by USF2 has been reported in sheep uterine arteries [32, 38] showing a complex relationship between both transcription factors. The action of $E_{2}$ through GPER1 not only may be involved on the USF2 protein synthesis or viability, but also on the USF2 activation through several pathways described for GPER1 [25, 39-41]. This aspect is of high relevance considering the important role, beside the cell-specificity, that specific phosphorylation plays on the activation of USF protein that modifies its function from tumor suppressor in prostate cancer to tumor promoter in lung cancer and thyroid cancer as recently Horbach et al. reported [15, 42].

Our first hypothesis was that the strong increase of USF2 induced by $E_{2}$ might stimulate the SF-1 transcription activating the E-box motif, which in turn may induce Cyp19A1 gene increasing the key enzyme $\mathrm{P}_{450}$ Arom. However, the discordance between the high USF2 protein expression and the weak binding observed on SF-1 E-Box DNA consensus studies suggests a partial effect of USF2 on SF-1 gene promoter in cell treated with $E_{2}$. Nevertheless, more studies are needed to confirm or to discard this pathway. Furthermore, the proinflammatory environment, generated by $\mathrm{PGE}_{2}$, was unable to modify USF2 variants protein, although induced a strong stimulation on SF- 1 and $\mathrm{P}_{450}$ Arom protein contents, indicating different regulations.

The up-regulation of $\mathrm{P}_{450}$ Arom by $\mathrm{PGE}_{2}$ through cAMP/CREB signaling pathway was previously reported $[1,11,12,43]$. The additive effect of $\mathrm{E}_{2}$ and $\mathrm{PGE}_{2}$ on $\mathrm{P}_{450}$ Arom protein contents indicates different activation mechanisms. Similar additive effect we reported previously in isolated control epithelial cells treated with peritoneal fluid from endometriosis women (PF-E) and $\mathrm{Bu}_{2}$ cAMP [44] mimicking the conditions of the endometriotic lesions. In our control epithelial cell model, $\mathrm{P}_{450}$ Arom stimulation by $\mathrm{E}_{2}$ was through ER $\alpha$ and GPER1, but not through ER $\beta$ as it was previously proposed $[1,45]$ probably by the use of isolated control epithelial cells and not endometriotic stromal cells. It is known the important role of SF-1 on steroid hormone biosynthesis, and also on development, differentiation, and function of the endocrine tissues [46]. The non-classic receptor GPER1 mediating the $\mathrm{E}_{2}$ stimulatory action on SF-1 protein content as shown by our G1 data, is in agreement with SF-1 activation and endometrial cell proliferation through the PI3K and MAPK pathways activated in several cell lines transfected with GPER1 $[39,40]$. However, cAMP pathway cannot be ruled out according to similar response to
$(\mathrm{Bu})_{2}$ cAMP of control or SF-1-transfected endometrial epithelial cells as we previously reported [44].

In the present study, control epithelial cells were sensitive to $E_{2}$ and/or $\mathrm{PGE}_{2}$ treatments, mimicking the estrogenic and pro-inflammatory microenvironment described in endometriosis, inducing abnormal molecule expression similarly to endometria from women with endometriosis as has been widely reported by several authors including our own group [14, 33-36, 47]. Very little information are regarding USF2, and even less about USF2 variants. Our data of sustained USF2 protein expression during the secretory phase in eutopic endometria of women with endometriosis, an invasive estrogen-dependent disease, and the fact that the USF2 action is cell specific and may change its function from tumor suppressor to tumor promoter with invasive characteristics $[15,42]$, suggest that USF2 may be involved in the pathophysiology of the endometriosis.

\section{Conclusions}

To our knowledge, this is the first report that shows USF2 variants protein expression patterns in human normal and pathologic endometria during the menstrual cycle and its $E_{2}$ stimulation mediated by ER $\alpha$ and GPER1 visualized by the response of cells obtained from control endometria, being unaffected the endogenously stimulated cells from endometriosis origin. The lack of $E_{2}$ stimulation on USF2/SF-1 E-Box/DNA-sequence binding and the absence of $\mathrm{PGE}_{2}$ effect on USF2 variants opposite to the strong induction that they exert on SF1 and P450 proteins suggest different mechanisms and regulations. The sustained USF2 protein expression during the secretory phase in eutopic endometria of women with endometriosis may participate in the pathophysiology of this disease strongly associated with infertility and its characteristic endometrial invasion to ectopic sites in the pelvic cavity.

\section{Methods \\ Subjects}

Eutopic endometrium was obtained from 37 women undergoing diagnostic laparoscopy for endometriosis associated with pain and/or infertility (endometriosis group), and 49 women without endometriosis undergoing laparoscopy for tubal ligation or hysterectomy for a benign non-endometrial gynecologic condition (control group) in the Clinical Hospital San Borja-Arriarán. The age of these women was $33.9 \pm 5.6$ years for the endometriosis group and $36.7 \pm 6.5$ years for the control group $(p<0.05)$. Both groups of women had abstained from any hormonal treatment for at least 3 months prior to surgery. Endometrial biopsies were obtained during surgery with Cornier pipelle suction curettage from the corpus of the uterus, kept in cold sterile phosphate buffer saline 
(PBS), and transported to the laboratory at $4{ }^{\circ} \mathrm{C}$. One piece of the tissue was fixed in formalin for histological evaluation, others pieces were frozen for protein studies or used for endometrial epithelial cells isolation.

The endometriosis grade was $49 \%$ minimal-mild (score 1-15 points) and $51 \%$ moderate-severe (score $\geq 16$ points) according to American Society of Reproductive Medicine criteria [48]. Endometriosis was diagnosed during surgery by visual evaluation by an experimented surgeon in each patient. This study was approved by the ethical committees of Faculty of Medicine of University of Chile and Metropolitan Central Health Service of Chile; each patient signed a written informed consent before surgery.

Endometrial samples were dated according to Noyes criteria [49] and classified as proliferative (days 6-14; 12 control and 9 endometriosis samples) phase or early (days 15-18; 12 control and 10 endometriosis), mid (days 19-23; 12 control and 10 endometriosis), and late secretory phase (days 24-28; 13 control and 8 endometriosis).

\section{Cell culture}

Secretory endometrium was washed in PBS, minced, and digested according to previous indication [50]. The glands were separated and cultured according to previous indication $[44,50]$ and after the first or second passage, the cells were reseeded in duplicate protein studies until subconfluence. Then, the cells were incubated in fetal bovine serum-free medium (defined-medium) for $24 \mathrm{~h}$, and treated for another $24 \mathrm{~h}$ in fresh defined-medium without (basal) or with prostaglandin $\mathrm{E}_{2}\left(\mathrm{PGE}_{2}, 10^{-8} \mathrm{~mol} / \mathrm{L}\right.$; Sigma), or $\mathrm{E}_{2}\left(10^{-8} \mathrm{~mol} / \mathrm{L}\right.$; Sigma). Increasing concentrations of Propylpyrazole-triol (PPT, $10^{-9}$ to $10^{-7} \mathrm{~mol} / \mathrm{L}$, Tocris Bioscience, Bristol, UK) and Diarylpropionitrile (DPN, $10^{-9}$ to $10^{-7} \mathrm{~mol} / \mathrm{L}$, Tocris), specific agonists of $\mathrm{ER} \alpha$ and ER $\beta$, respectively, or G1 $\left(10^{-8}\right.$ to $10^{-6} \mathrm{~mol} / \mathrm{L}$, Merck KGaA, Darmstadt, Germany) specific agonist of GPER1, were also added to cell cultures for $24 \mathrm{~h}$ in the presence or absence of ICI-182,780 ( $10^{-6} \mathrm{~mol} / \mathrm{L}, \mathrm{ER} \alpha$ and ER $\beta$ antagonist; Tocris) added 40 min before of ER agonists.

\section{Protein homogenate preparation}

Cytosolic and nuclear proteins from endometrial pieces and epithelial cells were obtained as previously reported [47]. The protein concentration was determined using the Bradford Assay reagent (BioRad, Hercules, CA, USA).

Thirty $\mu \mathrm{g}$ of cytosolic and nuclear proteins were denatured, resolved in $10 \%$ PAGE-SDS, and electrotransferred into nitrocellulose membranes (BioRad) as previously indicated $[44,50]$. After blocking with $5 \%$ BSA, the membranes were incubated overnight at $4{ }^{\circ} \mathrm{C}$ with primary antibodies against USF2 (polyclonal, 1:800; Abcam Inc, Cambridge, MA, USA), SF-1 (polyclonal, 1:800; ABR
Affinity BioReagents, Golden, CO., USA), $\mathrm{P}_{450}$ Arom (monoclonal; 1:600; Serotec, Oxford, UK), TFIIB (monoclonal, 1:500; BD Biosciences, MD, USA), or GAPDH (polyclonal; 1:5000; Abcam). The images were captured with Discovery10gD (Ultralum, Claremont, CA, USA) using UltraQuant 6.0.0.344 software, analyzed with CarestreamMI5.0.6.20 software (Carestream Health, Inc., Rochester, NY, USA). The results were normalized with GAPDH or TFIIB analysis for cytosolic or nuclear extracts, respectively.

\section{SF-1 E-Box DNA shift assay}

The assay was performed using LightShift Chemiluminescent EMSA kit (Thermo Scientific, Rockford, IL, USA). Briefly, $5 \mu \mathrm{g}$ nuclear proteins obtained as described above were incubated during $20 \mathrm{~min}$ at room temperature in a reaction mix which included $20 \mathrm{fmol}$ biotin endlabeled oligonucleotides that represented the SF-1 gene promoter containing the E-box (Integrated DNA Technologies, Inc., Coralville, IO, USA) following the manufacturer's indications and as described Utsunomiya et al. [17] For supershift study, nuclear proteins were previously incubated with $1 \mu \mathrm{g}$ USF2 antibody (Abcam) during $2 \mathrm{~h}$ at $4{ }^{\circ} \mathrm{C}$. The samples were resolved in non denaturing $4 \%$ polyacrylamide gel, electrotransferred to biodyneB membrane (Pall Corporation, Port Washington, NY, USA), which was UV-light crosslinked (UVP HL-2000 HybriLinker, Cambridge, UK), blocked and the label detected following the manufacturer's indications (Thermos). The images were captured with Discovery10gD using UltraQuant 6.0.0.344 software.

\section{Statistical analysis}

Results are expressed as mean \pm SEM. KolmogorovSmirnov test was used to evaluate normal distribution. When non-parametric distribution was present MannWhitney or Kruskal-Wallis tests were used, followed by a Dunn test. Means were expressed as percent of increase. Analysis of covariance (ANCOVA) was employed to test statistical interaction with co-variables like age and phases of the menstrual cycle.

\section{Abbreviations}

USF2: upstream stimulatory factor; SF-1: steroid factor-1; GPER1: G-coupled protein estrogen receptor 1; $\mathrm{P}_{450}$ Arom: aromatase enzyme; PPT: 4,4'4"-(4-Propyl-[1 H]-pyrazole-1,3,5-triyl)trisphenol; DPN: 2.3-bis(4-Hydroxyphenyl)propionitrile; ICI 182,780: 7 $\alpha, 17 \beta$-[9[4,4,5,5,5-Pentafluoropentyl]sulfinyl]nonyl] estra-1,3,5(10)-triene-3,17-diol; G1: 1-(4-(6-Bromobenzo[1,3]dioxol-5-yl)3a,4,5,9b-tetrahydro-3H-cyclopenta[c] quinolin-8-yl)-ethanone; $\mathrm{E}_{2}$ : estradiol; $\mathrm{PGE}_{2}$ : prostaglandin $\mathrm{E}_{2}$; $\mathrm{ER}$ : estrogen receptor.

\section{Authors' contributions}

JC participated in experimental protocols and drafted the manuscript. GA carried out cell cultures and EMSA/SS studies and in the analysis of data. PI and PH carried out cell cultures and immunoblots studies and the analysis of data. RG-R diagnosed the endometriosis during surgery, participated in the interpretation of data and helped reviewing the manuscript critically. 
HS diagnosed the endometriosis during surgery and participated in the interpretation of data. MAB participated in the interpretation of data, helped to draft the article and reviewed the manuscript critically. AF carried out the statistical analysis and helped in the interpretation of data and reviewing the manuscript critically. MCJ conceived and design the study as principal investigator; participated in the analysis and interpretation of data and drafting the manuscript. All authors read and approved the final manuscript.

\section{Author details}

${ }^{1}$ Faculty of Medicine, Institute of Maternal and Child Research, University of Chile, P.O. Box 226-3, Santiago, Chile. ${ }^{2}$ San Borja-Arriarán Clinical Hospital, Santiago, Chile.

\section{Acknowledgements}

The authors are grateful to the women who donated tissue, as this study would not have been possible without their generous contributions. This work was supported by FONDECYT\#1120074, Santiago, Chile.

\section{Competing interests}

The authors declared that they have no competing interests.

Received: 1 September 2015 Accepted: 30 September 2015 Published online: 09 October 2015

\section{References}

1. Bulun SE. Mechanisms of disease. Endometriosis. N Engl J Med. 2009;360:268-79.

2. Casals G, Ordi J, Creus M, Fábregues F, Carmona F, Casamitjana R, et al. Expression pattern of osteopontin and $\alpha \vee \beta 3$ integrin during the implantation window in infertile patients with early stages of endometriosis. Human Reprod. 2012;27:805-13.

3. Edwards A, Nakamura D, Virani S, Wessels J, Tayade C. Animal models for anti-angiogenic therapy in endometriosis. J Reprod Immunol. 2013;97:85-94.

4. McKinnon B, Bersinger NA, Wotzjow C, Mueller MD. Endometriosisassociated nerve fibers, peritoneal fluid cytokine concentrations, and pain in endometriotic lesions from different locations. Fertil Steril. 2012;97:373-80

5. Burney RO, Giudice LC. Pathogenesis and pathophysiology of endometriosis. Fertil Steril. 2012;98:511-9.

6. Sampson J. Peritoneal endometriosis due to the menstrual dissemination of endometrial tissue into the peritoneal cavity. Am J Obstet Gynecol. 1927;14:422-69.

7. Kokcu A. Possible effects of endometriosis-related immune events on reproductive function. Arch Gynecol Obstet. 2013;287:1225-33.

8. Attar E, Bulun SE. Aromatase and other steroidogenic genes in endometriosis: translational aspects. Human Reprod. 2006;12:49-56.

9. Dassen H, Punyadeera C, Kamps R, Delvoux B, Van Langendonckt A, Donnez J, et al. Estrogen metabolizing enzymes in endometrium and endometriosis. Human Reprod. 2007;22:49-56.

10. Izawa M, Harada T, Taniguchi F, Ohama Y, Takenaka Y, Terakawa N. An epigenetic disorder may cause aberrant expression of aromatase gene in endometriosic stromal cells. Fertil Steril. 2008;89(5 Suppl):1390-6.

11. Noble L, Simpson E, Johns A, Bulun S. Aromatase expression in endometriosis. J Clin Endocrinol Metab. 1996:81:174-9.

12. Noble LS, Takayama K, Zeitoun KM, Putman JM, Johns DA, Hinshelwood MM, et al. Prostaglandin E2 stimulates aromatase expression endometriosis-derived stromal cells. J Clin Endocrinol Metab. 1997;82:600-6.

13. Kitawaki J, Noguchi T, Amatsu T, Maeda K, Tsukamoto K, Yamamoto T, et al. Expression of aromatase cytochrome P450 protein and messenger ribonucleic acid in human endometriotic and adenomyotic tissues but not in normal endometrium. Biol Reprod. 1997;57:514-9.

14. Johnson MC, Pinto C, Alves A, Palomino A, Fuentes A, Boric MA, et al. P450Arom and estrogenic microenvironment of eutopic endometria in endometriosis. Rev Med Chile. 2004;132:1475-82.

15. Horbach T, Gotz C, Kietzmann T, Dimova EY. Protein kinases as switches for the function of upstream stimulatory factors: implications for tissue injury and cancer. Front Pharmacol. 2015;. doi:10.3389/fphar.2015.00003.
16. Chen N, Szentirmay MN, Pawar SA, Sirito M, Wang J, Wang Z, et al. Tumorsuppression function of trnascription factor USF2 in prostate carcinogenesis. Oncogene. 2006;25:579-87.

17. Utsunomiya $H$, Cheng Y, Lin Z, Reierstad S, Yin P, Attar E, et al. Upstream stimulatory factor-2 regulates steroidogenic factor-1 expression in endometriosis. Mol Endocrinol. 2008;22:904-14

18. Viollet B, Lefrançois-Martinez A, Henrion A, Kahn A, Raymondjean M, Martinez A. Immunochemical characterization and transacting properties of upstream stimulatory factor isoforms. J Biol Chem. 1996;271:1405-15.

19. Enmark E, Pelto-huikko M, Grandien K, et al. Human estrogen receptor beta-gene structure, chromosomal localization and expression pattern. J Clin Endocrinol Metab. 1997:82:4258-65.

20. Critchley HOD, Brenner RM, Henderson TA, Williams K, Nayak NR, Slayden $\mathrm{OD}$, et al. Estrogen receptor beta, but not estrogen receptor alpha is present in the vascular endothelium of the human and nohuman primate endometrium. J Clin Endocrinol Metab. 2001;86:1370-8.

21. Lecce G, Meduri G, Ancelin M, Bergeron C, Perrot-Applanat M. Presence of estrogen receptor beta in the human endometrium through the cycle: expression in glandular, stromal, and vascular cells. J Clin Endocrinol Metab. 2001;86:1379-86.

22. Frasor J, Barnett DH, Danes JM, Hess R, Parlow AF, Katzenellenbogen BS. Response-specific and ligand dose-dependent modulation of estrogen receptor (ER) alpha activity by ERbeta in the uterus. Endocrinology. 2003;144:3159-66.

23. Hall JM, McDonnell DP. The estrogen receptor beta-isoform (ERbeta) of the human estrogen receptor modulates ERalpha transcriptional activity and is a key regulator of the cellular response to estrogens and antiestrogens. Endocrinology. 1999;140:5566-78.

24. Lessey BA, Palomino WA, Apparao KB, Young SL, Lininger RA. Estrogen receptor-alpha (ER-alpha) and defects in uterine receptivity in women. Reprod Biol Endocrinol. 2006;4(Suppl 1):S9.

25. Thomas $P$, Pang Y, Filardo EJ, Dong J. Identity of an estrogen membrane receptor coupled to a $G$ protein in human breast cancer cells. Endocrinology. 2005;146:624-32.

26. Revankar CM, Revankar CM, Cimino DF, Sklar LA, Arterburn JB, Prossnitz ER. A transmembrane intracellular estrogen receptor mediates rapid cell signaling. Science. 2005;307:1625-30.

27. Hammes SR, Levin ER. Extranuclear steroid receptors: nature and actions. Endocrinology. 2007;28:726-41.

28. Kolkova Z, Noskova V, Ehinger A, Hansson S, Cassién B. G protein-coupled estrogen receptor I (GPER1, GPR 30) in normal human endometrium and early pregnancy decidua. Mol Hum Reprod. 2010;16:746-51.

29. Plante BJ, Lessey BA, Taylor RN, Wang E, Bagchi MK, Yuan L, et al. G Protein-coupled estrogen receptor (GPER) expression in normal and aberrant endometrium. Reprod Sci. 2012;19:684-93.

30. Velasco I, Rueda J, Acién P. Aromatase expression in endometriotic tissues and cell cultures of patients with endometriosis. Mol Human Reprod. 2006;12:377-81.

31. Maia H Jr, Haddad C, Casoy J. Correlation between aromatase expression in the eutopic endometrium of symptomatic patients and the presence of endometriosis. Int J Women Health. 2012;4:61-5.

32. Hudelist G, Czerwenka K, Keckstein J, Haas C, Fink-Retter A, GschwantlerKaulich D, et al. Expression of aromatase and estrogen sulfotransferase in eutopic and ectopic endometrium: evidence for unbalanced estradiol production in endometriosis. Reprod Sci. 2007;14:798-805.

33. Kao LC, Germeyer A, Tulac S, Lobo S, Yang JP, Taylor RN, et al. Expression profiling of endometrium from women with endometrisis reveals candidate genes for disease-based implantation failure and infertility. Endocrinology. 2003;144:2870-81.

34. Johnson M, Torres M, Alves A, Bacallao K, Fuentes A, Vega M, et al. Augmented cell survival in eutopic endometrium from women with endometriosis: expression of c-myc, TGF-beta1 and bax genes. Reprod Biol Endocrinol. 2005:8:45-52.

35. Ponce C, Torres M, Galleguillos C, Sovino H, Boric MA, Fuentes A, et al. Nuclear factor kappaB pathway and interleukin-6 are affected in eutopic endometrium of women with endometriosis. Reproduction. 2009;137:727-37

36. Zhang H, Niu Y, Feng J, Guo H, Ye X, Cui H. Use of proteomic analysis of endometriosis to identified different protein expression in patients with endometriosis versus normal controls. Fertil Steril. 2006:86:274-82. 
37. Robertson JA, Zhang Y, Ing NH. ICI 182,780 acts as a partial agonist and antagonist of estradiol effects in specific cells of the sheep uterus. J Steroid Biochem Mol Biol. 2001;77(4-5):281-7.

38. Dasgupta C, Chen M, Zhang H, Yang S, Zhang L. Chronic hypoxia during gestation causes epigenetic repression of ERagene in ovine uterine arteries via heightened promoter methylation. Hypertension. 2012;60:697-704

39. Ge X, Guo R, Qiao Y, Zhang Y, Lei J, Wang X, et al. The G protein-coupled receptor GPR30 mediates the nontranscriptional effect of estrogen on the activation of PI3K/Akt pathway in endometrial cancer cells. Int J Gynecol Cancer. 2013;23:52-9.

40. He YY, Cai B, Yang YX, Liu XL, Wan XP. Estrogenic G protein-coupled receptor 30 signaling is involved in regulation of endometrial carcinoma by promoting proliferation, invasion potential, and interleukin- 6 secretion via the MEK/ERK mitogen-activated protein kinase pathway. Cancer Sci. 2009;100:1051-61.

41. Lin BC, Suzawa M, Blind RD, Tobias SC, Bulun SE, Scanlan TS, et al. Stimulating GPR30 estrogen receptor with a novel tamoxifen analogue activates SF-1 and promotes endometrial cell proliferation. Cancer Res. 2009;69:5415-23.

42. Horbach T, Chi TF, Gotz C, Sharma S, Juffer AH, Dimova EY, et al. GSK3 $\beta$ dependent phosphorylation alters DNA binding transactivity amd half-life of the transcription factor USF2. PLoS One. 2014;9:e107914. doi:10.1371/journal.pone.0107914.

43. Trukhacheva E, Lin Z, Reierstad S, Cheng YH, Millas M, Bulun SE. Estrogen receptor (ER) $\beta$ regulates $E R \alpha$ expression in stromal cells derived from ovarian endometriosis. J Clin Endocrinol Metab. 2009;94:615-22.
44. Castro J, Torres M, Sovino H, Fuentes A, Boric MA, Johnson MC. P450Arom induction in isolated control endometrial cells by peritoneal fluid from women with endometriosis. Fertil Steril. 2010;94:2521-7.

45. Knapp P, Chabowski A, Blachnio-Zabielska A, Walentowicz-Sadlecka M. Expression of estrogen receptors $(\alpha, \beta)$, cycloxygenase- 2 and aromatase in normal endometrium and endometrioid cancer of uterus. Adv Med Sci. 2013;58:96-103

46. Val P, Lefrançois-Martinez AM, Veyssière G, Martinez A. SF-1 a key player in the development and differentiation of steroidogenic tissues. Nuclear Recept. 2003;1:8-30

47. Vouk K, Smuc T, Guggenberger C, Ribic-Pucelj M, Sinkovec J, Husen B, et al. Novel estrogen-related genes and potential biomarkers of ovarian endometriosis identified by differential expression analysis. J Steroid Biochem Mol Biol. 2011;125:231-42.

48. American Society For Reproductive Medicine. Revised American Society for Reproductive Medicine classification of endometriosis. Fertil Steril. 1997;67:817-21

49. Noyes R, Hertig A, Rock J. Dating the endometrial biopsy. Fertil Steril. 1950;1:3-25.

50. Pino M, Galleguillos C, Torres M, Sovino H, Fuentes A, Boric MA, et al. Association between MMP1 and MMP9 activities and ICAM1 cleavage induced by TNF in stromal cell cultures from eutopic endometria of women with endometriosis. Reproduction. 2009;138:837-47.

\section{Submit your next manuscript to BioMed Central and take full advantage of:}

- Convenient online submission

- Thorough peer review

- No space constraints or color figure charges

- Immediate publication on acceptance

- Inclusion in PubMed, CAS, Scopus and Google Scholar

- Research which is freely available for redistribution

Submit your manuscript at 